\title{
Obituary: Keith Madelin
}

Keith Madelin, former County Surveyor of Shropshire and Professor of Civil Engineering at the University of Birmingham, died suddenly on 30th December 2019.

In 1994, Keith was awarded the OBE for services to transportation with a successful career in local government for over 35 years before becoming an academic.

His first appointment was with Staffordshire County Council in 1960 and after gaining an MSc in Transportation and Environmental Planning in 1964 his career took him to the North-East in 1965.

Initially appointed to Gateshead County Borough Council as Principal Traffic Engineer, he then moved to Teesside County Borough on appointment as Chief Assistant Traffic Engineer in 1968 and was promoted to Assistant Borough Engineer in 1970. Following national local government reorganisation, Keith became Deputy County Surveyor in 1973 with Cleveland County Council.

In 1974, Keith returned to the West Midlands as the Metropolitan County Council Deputy County Surveyor, from where he was appointed County Surveyor to Shropshire County Council from 1982 to 1995.

During this period, he was Highways Adviser to the Metropolitan and County Councils Association (1980-1992) and to the Transport Research Laboratory (1989-1993). He became a member (1984-1987) of the Standing Committee on Highway Maintenance for the UK and responsible for the National Road Maintenance Condition Survey. Keith was also a member and Chairman of the National Highways and Utilities Committee, which advised the UK government on new legislation and prepared codes of practice.

As Technical Secretary to the Steering Group he was prime author of the first Code of Practice for Highways Maintenance, published in 1983.

Keith became a UK member of the PIARC (World Road Association) Road Management Committee from 1987 to 1999 and Vice Chairman from 1995 onwards, becoming leader of the PIARC group studying maintenance management systems (1987-1991).

After being Secretary of the County Surveyors Society from 1984 to 1987 he became President in 1993.

In 1996, Keith moved to the University of Birmingham, initially as a Lecturer to the MSc Highway Management and Engineering Course on Maintenance Management and to the Senior Executives Road Programme sponsored by the World Bank.

He was appointed Professor of Civil Engineering and in this role established railway research as a new topic within the civil engineering department in 1998. This was followed by the creation of a multi-disciplinary railway research centre at the University of Birmingham (2001).

In 2003, he established Birmingham as the lead university (with Southampton) and headquarters for a new Engineering and Physical Sciences Research Council-funded virtual railway research centre - Rail Research UK, a consortium of 12 research groups from seven universities becoming Director and head of Rail Research UK.

Keith became a member of the Institution of Civil Engineers (ICE) in 1968 , a Fellow in 1984 and a Fellow of the Chartered Institution of Highways and Transportation in 1983.

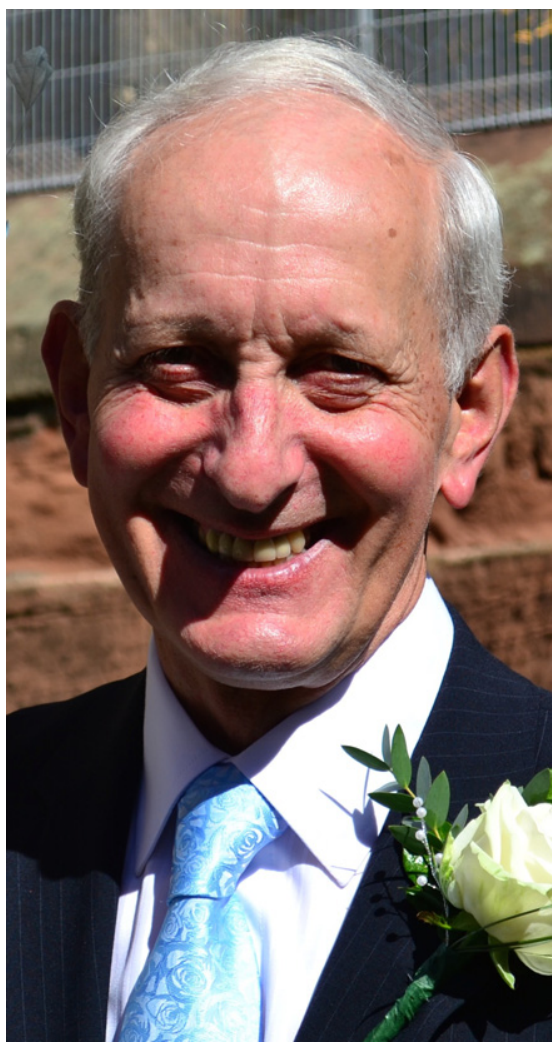

Keith Madelin OBE: 1941-2019

Former PIARC Committee colleagues knew Keith as a charming individual a good communicator and a solid engineer, who was forward-thinking and someone ready to 'push the envelope in advancing technologies for transportation': a worthy professional epitaph.

After retirement in 2005, Keith became an active contributor to and Chairman of the West Midlands ICE Senior Members Group.

For 45 years Keith was a very active member of the community of Trinity Church, Codsall. He served on numerous committees, founded and ran the youth club and in recent years acted as treasurer.

For many years Keith played a good game of cricket, as a medium-pace bowler but mainly as a handy batsman. He also played tennis and was still an active squash player in addition to golf, a sport he turned to in later years and played weekly.

Keith is survived by his sons Peter and Stephen by his first wife Jill, who died in 2006

He leaves his wife Ruth, stepdaughter Mary and stepson James. 